\begin{tabular}{|c|c|c|}
\hline BIODIK & $\begin{array}{c}\text { BIODIK: Jurnal IImiah Pendidikan Biologi } \\
\text { ISSN 2580-0922 (online), ISSN 2460-2612 (print) } \\
\text { Volume 07, Nomor 03, Tahun 2021, Hal. 144-155 } \\
\quad \text { Available online at: } \\
\text { https://online-journal.unja.ac.id/biodik }\end{array}$ & BIODIK \\
\hline
\end{tabular}

Research Article OPEN ACCESS

\title{
Analisis Lembar Kerja Peserta Didik Materi Pencemaran Lingkungan Dengan Metode ANCOR
}

\author{
(Student Worksheet Analysis of Environmental Pollution Materials \\ Using ANCOR Method)
}

\author{
Zakiah Nurfadilah , Bambang Supriatno, Sri Anggraeni \\ Program Studi Pendidikan Biologi, Fakultas Pendidikan Matematika dan Ilmu Pengetahuan Alam \\ Universitas Pendidikan Indonesia \\ JI. Dr. Setiabudi No.229, Isola, Kec. Sukasari, Kota Bandung, Jawa Barat-Indonesia 40154 \\ ${ }^{*}$ Corresponding author : zakiahnurfadilah@gmail.com
}

\begin{tabular}{|c|c|}
\hline Informasi Artikel & ABSTRACT \\
\hline $\begin{array}{l}\text { Submit: } 02-06-2021 \\
\text { Diterima: } 31-08-2021 \\
\text { Dipublikasikan: } 29-09-2021\end{array}$ & $\begin{array}{l}\text { The practicum method is a method that can be used for student learning. By } \\
\text { using practicum, students will need a guide in the form of a worksheet in order } \\
\text { to carry out practical activities in accordance with the guidelines. This objective } \\
\text { is aimed at (1) obtaining an overview of the suitability of the practicum following } \\
\text { the steps of LKPD, (2) knowing how practicum can be carried out in accordance } \\
\text { with LKPD and curriculum, (3) knowing the existence of an overview related to } \\
\text { practicum objectives, principles and concepts in LKPD, (4) to find out whether } \\
\text { the steps in LKPD can provide direction to students. The method used in this } \\
\text { research is descriptive qualitative method with ANCORB stages, namely (1) } \\
\text { Analysis, (2) Testing, (3) Reconstruction. To carry out the analysis, the analysis } \\
\text { is carried out through aspects of relevance, aspects of competence, aspects of } \\
\text { knowledge construction, practical analysis and reconstruction. The research } \\
\text { object uses } 5 \text { LKPD regarding environmental pollution. The results showed that } \\
\text { there was still a lot of confusion among students because the research steps } \\
\text { were not clear. This study concludes that there is a need for improvements to } \\
\text { the Environmental Pollution LKPD material in order to produce a better } \\
\text { Environmental Pollution LKPD. } \\
\text { Key words: Student Worksheet, Environmental Pollution, ANCOR }\end{array}$ \\
\hline Penerbit & ABSTRAK \\
\hline $\begin{array}{l}\text { Program Studi Pendidikan Biologi } \\
\text { FKIP Universitas Jambi, } \\
\text { Jambi- Indonesia }\end{array}$ & $\begin{array}{l}\text { Metode praktikum dalam metode yang dapat digunakan untuk pembelajaran } \\
\text { siswa. Dengan menggunakan praktikum, maka siswa akan memerlukan } \\
\text { panduan berupa lembar kerja agar dapat melakukan kegiatan praktikum yang } \\
\text { sesuai dengan panduan. Penelitian ini bertujuan untuk (1) memperoleh } \\
\text { gambaran pada kesesuaian praktikum yang mengikuti langkah LKPD, (2) } \\
\text { mengetahi bagaimana praktikum dapat dilakukan sesuai dengan LKPD dan } \\
\text { kurikulum, (3) mengetahui adanya gambaran terkait tujuan praktikum, prinsip } \\
\text { dan konsep dalam LKPD, (4) untuk mengetahui apakah langkah yang ada pada } \\
\text { LKPD dapat memberikan arahan terhadap siswa. Metode yang digunakan } \\
\text { dalam penelitian ini adalah metode kualitatif deskriptif dengan tahapan ANCOR } \\
\text { yaitu (1) Analisis, (2) Uji Coba, (3) Rekonstruksi. Untuk melakukan analisis, } \\
\text { analisis dilakukan melalui aspek relevansi, aspek kompetensi, aspek konstruksi } \\
\text { pengetahuan, analisis praktikal dan rekonstruksi. Objek penelitian } \\
\text { menggunakan } 5 \text { LKPD mengenai pencemaran lingkungan. Hasil penelitian } \\
\text { menunjukan masih banyak kebingungan diantara siswa karena langkah } \\
\text { penelitian yang tidak jelas. Penelitian ini menyimpulkan perlu adanya perbaikan }\end{array}$ \\
\hline
\end{tabular}


pada LKPD materi Pencemaran Lingkungan agar dapat menghasilkan LKPD Pencemaran Lingkungan yang lebih baik.

Kata kunci: Lembar Kerja Peserta Didik, Pencemaran Lingkungan, ANCOR

c) (1) (8) (2)

EY Ne

This BIODIK : Jurnal IImiah Pendidikan Biologi is licensed under a CC BY-NC-SA (Creative Commons Attribution-ShareAlike 4.0 International License)

\section{PENDAHULUAN}

Perkembangan yang terjadi di abad 21 ini sangatlah pesat salah satunya yaitu perkembangan pendidikan. Menurut putri (2016) pendidikan adalah salah satu kunci untuk memajukan dan mengembangkan sumber daya yang ada menjadi lebih baik. Pendidikan membentuk dasar dari segala sesuatu di dunia saat ini termasuk pendidikan lingkungan. Pendidikan Lingkungan memberikan pengetahuan tentang situasi saat ini dan prospek masa depan alam. Menurut Hasibuan (2016) memahami permasalahan lingkungan dan mampu mengelola lingkungan tanpa merusaknya adalah salah satu hal yang dapat menjaga keadaan lingkungan tetap baik. Untuk memahami dan mengelola lingkungan dengan baik tentunya membutuhkan pendidikan dan pengetahuan mengenai lingkungan dengan baik pula. Pada saat ini banyak lembaga mengajarkan masyarakat untuk mengeksplorasi permasalahan yang berkaitan dengan lingkungan, dan mampu mengelola lingkungan untuk melestarikannya. Menurut Pratama (2020) pemerintah saat ini dibantu oleh beberapa organisasi atau lembaga yang berkaitan memberikan penyuluhan atau edukasi kepada masyarakat mengenai pentingnya menjaga lingkungan dan cara pengelolaan lingkungan agar tetap terjaga. Pengetahuan lingkungan ini diharapkan mampu membuka pemikiran masyarakat untuk selalu menjaga kelestarian lingkungan. Kegiatan ini dilakukan langsung ke masyarakat maupun ke tempat-tempat tertentu seperti sekolah. Banyak sekolah telah melaksankan himbauan kepedulian lingkungan dengan cara memberikan pengetahuan praktis dan teoritis tentang dampak aktivitas manusia terhadap alam. Guru-guru mengajak siswa untuk keluar kelas dan mengarahkan siswa untuk melakukan aktivitas seperti berkebun, menyiram tanaman, meditasi di taman komunitas, dan lain-lain. Pendidikan adalah satu-satunya cara untuk membuat pikiran terbaik bekerja secara produktif (Arnop et al., 2019). Di era ini, alam berada di bawah ancaman. Berbagai spesies Flora dan Fauna berada di ambang kepunahan, udara yang kita hirup, air yang kita minum, makanan yang kita makan, semuanya tercemar atau mengandung kontaminan (Permadi \& Murni, 2013). Dengan memasukkan studi Lingkungan sebagai mata pelajaran di sekolah, serta di pendidikan tinggi, kita dapat membuat generasi mendatang lebih peka dan mendorong mereka untuk menemukan solusi dan metode inovatif untuk masa depan, untuk melindungi alam.

LKPD adalah Lembar Kerja Peserta Didik yang dibuat untuk melengkapi kebutuhan siswa di dunia pendidikan sebagai langkah pembantu siswa dalam mengerjakan tugas (Lampung, 2013). LKPD berfungsi untuk membantu serta mempermudah dalam kegiatan belajar yang nantinyaakan membentuk interaksi efektif antara peserta didik dengan para pengajar yang akan meningkatkan prestasi belajar peserta didik (li et al., 2012). LKPD dibutuhkan untuk mendukung dilakukannya praktikum, karena dengan adanya LKPD akan memudahkan proses praktikum dimana siswa dapat mencatat apa saja hasil dari praktikumnya (Studi et al., n.d.). LKPD memiliki kelebihan yaitu mempermudah siswa dalam menyelesaikan praktikum, siswa dapat menganalisa dengan baik apa yang sedang di uji dan meningkatkan pemahaman siswa untuk melakukan studi ilmiah lanjutan. Namun, LKPD perlu diperbaiki karena masih banyak kelemahannya, diantaranya adalah hanya berbentuk soal tanpa penjelasan yang jelas dan menyebabkan kurang pemahaman siswa terkait apa yang dikerjakan, tidak dapat menampilkan 
gerak melalui media visual, biaya lebih mahal karena melalui percetakan bukan visual, serta pembagian pembelajaran yang terlalu baku dan cenderung membuat siswa bosan (Ariani et al., 2020).

Kelemahan tersebut menjadi dasar diperlukan adanya rekonstruksi LKPD, dimana LKPD saat ini harus dilakukan perubahan agar dapat memperjelas dan mempermudah pemahaman siswa terkait apa saja yang harus dikerjakannya saat praktikum tersebut berlangsung. Dengan adanya rekonstruksi LKPD, diharapkan akan membentuk pengetahuan baru kepada siswa dan keterampilan, memberikan pemahaman baru terkait sistem praktikum, serta mengembangkan bakat dan minat siswa. Pada materi pencemaran lingkungan sendiri harus benar dilakukan karena jika salah akan menimbulkan arti yang berbeda. Contohnya, jika buang sampah sembarangan dapat menimbulkan banjir, kemudian siswa salah menganalisanya, maka bisa saja buang sampah sembarangan tidak menimbulkan banjir. Maka dari itulah diperlukan rekonstruksi LKPD agar siswa dapat memperjuangkan perlindungan lingkungan dan menciptakan lingkungan yang lebih baik. Selain itu, siswa diharapkan mampu mengamati pemanasan global mengubah iklim menjadi lebih hangat dan banjir mendorong pertumbuhan hama dan vektor seperti malaria dan demam berdarah untuk menyebarkan penyakit ke lingkungan yang meningkatkan tingkat kebutuhan oksigen biokimia.

Pencemaran lingkungan adalah masuk atau dimasukkannya makhluk hidup yang merugikan terhadap lingkungan, Menurut (Hasibuan, 2016), pencemaran lingkungan dibagi menjadi lima jenis sebagai berikut : (1) pencemaran udara, (2) pencemaran udara, (3) pencemaran tanah, (4) pencemaran suara, (5) pencemaran cahaya.

Melihat kelima faktor pencemaran diatas, maka kegiatan pembelajaran terhadap siswa harus digalakkan terkait pencemaran lingkungan karena hal ini akan menjadi dasar untuk memastikan bahwa kebutuhan generasi masa depan dipenuhi oleh sumber daya bumi, akan menjadi bentuk konsumsi berkelanjutan dari sumber daya tersebut saat ini (Pratama et al., 2020). Untuk mengatasi masalah tersebut maka LKPD menjadi hal yang dapat dilakukan siswa untuk mehami pencemaran lingkungan dan diharapkan siswa akan memahami bahwa pencemaran lingkungan yang terjadi menyebabkan sumber daya alam akan habis terlalu cepat bagi generasi mendatang untuk bertahan hidup. Penggunaan sumber daya ini secara tidak bertanggung jawab akan membuat generasi masa depan kita menanggung konsekuensi dari eksploitasi ini. Pendidikan lingkungan membantu orang memahami dampak yang disebabkan oleh eksploitasi berlebihan, dan bertindak sesuai dengan itu (Landrigan \& Fuller, 2015).

Berdasarkan latar belakang diatas penulis akan melakukan penelitian dengan melakukan suatu percobaan kemudian akan dianalisa dengan menggunakan desain kegiatan laboratorium yang tersedia dan sering digunakan guru terkait praktek pencemaran lingkungan. Tujuan dari penelitian ini adalah (1) mendapatkan gambaran yang berkaitan dengan tujuan praktikum dan LKPD sesuai kompetensi dasar pada kurikulum, (2) mengetahui adanya kesamaan antara tujuan dan langkah kerja praktikum di LKPD, (3) mengetahui prinsip dan konsep pada LKPD, (4) untuk mengetahui apakah langkah yang ada pada LKPD sudah mampu mengarahkan siswa pada konstruksi pengetahuan.

\section{METODE PENELITIAN}

Penelitian ini menggunakan metode kualitatif deskriptif, dimana penelitian kualitatif mengumpulkan data secara kualitatif yang bertujuan untuk menyajikan kondisi nyata pada suatu fenomena (Sugiyono,2017). Penelitian ini dilakukan untuk menguji coba Lembar Kerja Peseta Didik (LKPD) praktikum materi pencemaran lingkungan kelas X SMA yang berasal dari beberapa sumber. Pemilihan sampel menggunakan teknik purposive sampling dengan jumlah 5 LKPD dengan yang terdiri dari 2 LKPD yang berasal dari buku paket Biologi KTSP 2006, 2 LKPD dari buku paket Biologi Kurikulum 2013 dan 1 LKPD yang berasal dari internet. Metode analisisnya juga terutama kualitatif dengan tahapan ANCORB, 
yaitu (1) Analisis, (2) Uji Coba, (3) Rekonstruksi. Untuk melakukan analisis, analisis dilakukan melalui aspek relevansi, aspek kompetensi, aspek pengetahuan, dan analisis praktikal yang diadaptasi dari teori Noval dan Gowin dan kemudian akan dilanjutkan dengan rekonstuksi LKPD.

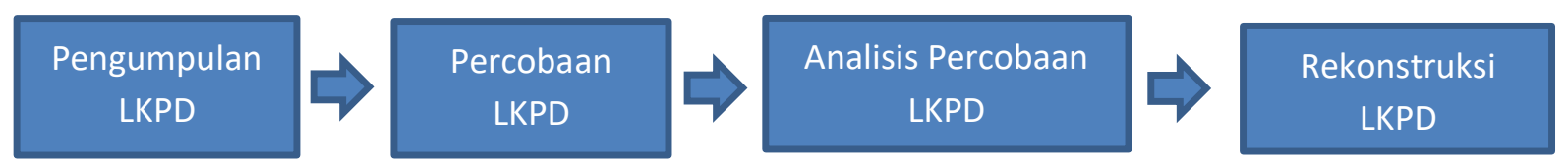

Gambar 1. Bagan sistematika ANCORB

\section{HASIL PENELITIAN DAN PEMBAHASAN}

Pendidikan merupakan hal yang dibutuhkan bagi semua orang karena dengan pendidikan akan mencerdaskan hidup bangsa. Untuk mendukung pendidikan, dibutuhkan proses pembelajaran yang baik dengan dukungan sarana yang baik pula. Kegiatan praktikum dapat memberikan pengalaman yang nyata bagi siswa dikalangan para siswa dibutuhkan adanya LKPD atau Lembar Kerja Peserta Didik untuk mendukung jalannya pendidikan. LKPD dibutuhkan agar bisa mendukung jalannya praktikum agar siswa memahami maksud dan tujuan dari apa yang sedang dilakukan.

\section{Aspek Relevansi}

Analisis relevansi pada materi konten kegiatan praktikum yang telah dilakukan menghasilkan data tabel 1.

Tabel 1. Hasil Analisis Aspek Relevansi

\begin{tabular}{|c|c|c|c|c|c|c|c|}
\hline \multirow{2}{*}{ Indikator } & \multirow{2}{*}{$\begin{array}{l}\text { Skor } \\
\text { Maks }\end{array}$} & \multicolumn{5}{|c|}{ LKPD } & \multirow[t]{2}{*}{ Hasil } \\
\hline & & 1 & 2 & 3 & 4 & 5 & \\
\hline $\begin{array}{l}\text { Kompetensi LKPD sesuai dengan } \\
\text { tuntutan KD }\end{array}$ & 2 & 1 & 1 & 1 & 1 & 1 & $\begin{array}{l}\text { Skor } 1=100 \% \\
\text { Skor } 2=0 \%\end{array}$ \\
\hline Konten pada LKPD sesuai dengan KD & 2 & 1 & 1 & 1 & 1 & 0 & $\begin{array}{l}\text { Skor } 0=20 \% \\
\text { Skor } 1=80 \%\end{array}$ \\
\hline
\end{tabular}

Pada aspek relevansi terhadap kegiatan dan kurikulum, KD yang harus dimiliki siswa kelas $\mathrm{X}$ pada pencemaran lingkungan yaitu KD 4.11 merumuskan gagasan pemecahan masalah perubahan lingkungan yang terjadi di lingkungan sekitar. Hasil diperoleh yaitu 5 LKPD memiliki Kompetensi yang dikembangkan pada kegiatan praktikum memenuhi standar minimal KD dengan persentase $100 \%$. Hal ini menunjukan bahwa 5 LKPD sudah sesuai dengan tuntutan KD. Konten yang terkandung dalam LKPD hendak memuat delapan unsur penting spaalah satunya yaitu kesesuaian kompetensi dasar yang akan dicapai (Putri, 2016). Pada Indikator konten dengan KD 20\% konten pada kegiatan praktikum dengan tidak memenuhi standar minimal KD dan 80\% sudah memenuhi standar minimal KD. Pada penyusunan desain kegiatan praktikum, kompetensi dasar merupakan salah satu tujuan yang utama pada pembelajaran. Sehingga kompetensi dan konten harus sejalan dengan kompetensi dasar. Tidak sesuainya konten pada LKPD dapat menyebabkan rendahnya kompetensi yang dimuat dan kemampuan kognitif yang rendah pada siswa (Ramadhayanti et al, 2020) Jika digambarkan, maka terbentuklah grafik yang dapat dilihat pada gambar 2 . 


\section{Aspek Relevansi}

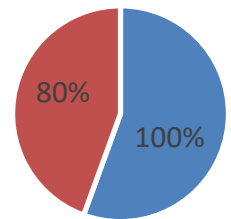

- Kompetensi LKPD sesuai dengan tuntutan KD

- Konten pada LKPD sesuai dengan KD

\section{Gambar 2. Aspek Relevansi}

\section{Aspek Kompetensi}

Aspek kompetensi dilakukan guna menguji kemampuan observasi LKPD yang mengobservasi karakter umum dan spesifik yang dihasilkan data pada tabel 2.

Tabel 2. Hasil Analisis Aspek Kompetensi

\begin{tabular}{|c|c|c|c|c|c|c|c|}
\hline \multirow{2}{*}{ Indikator } & \multirow{2}{*}{$\begin{array}{l}\text { Skor } \\
\text { Maks }\end{array}$} & \multicolumn{5}{|c|}{ LKPD } & \multirow[t]{2}{*}{ Hasil } \\
\hline & & 1 & 2 & 3 & 4 & 5 & \\
\hline Kemampuan observasi & 3 & 2 & 2 & 1 & 2 & 1 & $\begin{array}{l}\text { Skor } 1=40 \% \\
\text { Skor } 2=60 \%\end{array}$ \\
\hline Transformasi data & 3 & 2 & 3 & 1 & 2 & 1 & $\begin{array}{l}\text { Skor } 1=40 \% \\
\text { Skor } 2=40 \% \\
\text { Skor } 3=20 \%\end{array}$ \\
\hline Interpretasi data & 4 & 2 & 3 & 2 & 1 & 2 & $\begin{array}{l}\text { Skor } 1=50 \% \\
\text { Skor } 2=20 \% \\
\text { Skor 3 }=30 \%\end{array}$ \\
\hline Level kemampuan berpikir tingkat tinggi & 3 & 1 & 2 & 1 & 1 & 1 & $\begin{array}{l}\text { Skor } 1=80 \% \\
\text { Skor } 2=20 \%\end{array}$ \\
\hline
\end{tabular}

Pada aspek kompetensi ini indikator kemampuan observasi 5 LKPD memperoleh hasil 40\% LKPD hanya mengobservasi karakter umum dari objek/fenomena. Kemudian 60\% dari 5 LKPD mengobservasi karakter umum dan karakter spesifik dari objek/fenomena. Hal ini menunjukan jika 5 LKPD hanya mengarahkan siswa untuk mengobservasi karakter umu pada suatu objek fenomena. Tujuan dari dilaksankannya praktikum yaitu untuk memberikan kesempatan kepada siswa untuk mengobservasi fenomena secara nyata (Ridwan et al, 2020). Sedangkan pada indikator transformasi menunjukan 40\% dari 5 LKPD yang tersedia memiliki data kualitatif atau kuantitatif direpresentasikan kedalam bentuk standar (Deskripsi untuk data kualitatif/ grafik untuk data kuantitatif), 40\% 5 LKPD memiliki data kualitatif yang direpresentasikan kedalam bentuk lain namun tidak membantu proses interpensi data, dan 20\% 5 LKPD memiliki data kualitatif yang direpresentasikan kedalam bentuk lain yang membantu proses interpensi data. Hal ini menunjukan bahwa LKPD sudah mengarahkan siswa untuk merepresentasikan data namun hanya dalam bentuk standar dan juga mengarahkan untuk mengubah data ke bentuk lain namun tidak membantu dalam interpretasi data praktikum. Level Kemampuan berpikir tingkat tinggi $80 \%$ kegiatan praktikum hanya melibatkan kemampuan berpikir level mengarahkan siswa untuk berpikir level mengaplikasikan (C3). Kegiatan praktikum ditujukan untuk memberikan kesempatan pada siswa untuk mengamati dan menganalisis hasil atau fenomena yang didapatkan setelah diadakannya praktikum guna meningkatkan pengalamannya (Ridwan et al, 2020). 
Hal ini artinya kegiatan praktikum tersebut hanya melibatkan kemampuan berpikir tingkat menengah yang jika dibuatkan grafik maka dapat dilihat pada gambar 3 .

\section{Aspek Kompetensi}

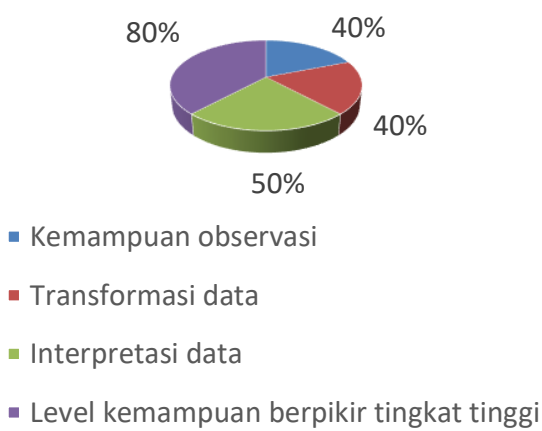

Gambar 3. Aspek kompetensi

\section{Aspek Pengetahuan}

Aspek konstruksi pengetahuan dilakukan guna menguji peristiwa yang sebenarnya terjadi dan dapat diidentifikasi yang dihasilkan data pada tabel 3 .

Tabel 3. Hasil Analisis Aspek Pengetahuan

\begin{tabular}{|c|c|c|c|c|c|c|c|}
\hline \multirow[t]{2}{*}{ Indikator } & \multirow{2}{*}{$\begin{array}{l}\text { Skor } \\
\text { maks. }\end{array}$} & \multicolumn{5}{|c|}{ LKPD } & \multirow[t]{2}{*}{ Hasil } \\
\hline & & 1 & 2 & 3 & 4 & 5 & \\
\hline Judul/Tujuan/Pertanyaan fokus & 3 & 2 & 2 & 2 & 1 & 2 & $\begin{array}{l}\text { Skor } 1=20 \% \\
\text { Skor } 2=80 \%\end{array}$ \\
\hline Objek fenomena & 3 & 2 & 1 & 2 & 2 & 1 & $\begin{array}{l}\text { Skor } 1=40 \% \\
\text { Skor } 2=60 \%\end{array}$ \\
\hline Teori, prinsip, dan konsep & 4 & 2 & 2 & 1 & 2 & 1 & $\begin{array}{l}\text { Skor 1 }=40 \% \\
\text { Skor 2 }=60 \%\end{array}$ \\
\hline Perekaman dan transformasi data & 4 & 3 & 3 & 2 & 2 & 2 & $\begin{array}{l}\text { Skor 2 }=60 \% \\
\text { Skor 3 }=40 \%\end{array}$ \\
\hline Perolehan pengetahuan & 4 & 2 & 3 & 2 & 1 & 1 & $\begin{array}{l}\text { Skor } 1=40 \% \\
\text { Skor 2 }=40 \% \\
\text { Skor 3 }=20 \%\end{array}$ \\
\hline
\end{tabular}

Berdasarkan tabel data tersebut, maka Aspek lain yaitu konstruksi pengetahuan, $80 \%$ atau 4 dari 5 LKPD sudah memiliki judul/tujuan/pertanyaan fokus meliputi bagian konseptual yang dapat digunakan serta mendukung peristiwa utama dan memperkuat objek. Menurut Ramadhayanti et al (2020) judul dan tujuan praktikum sangatlah penting agar kegiatan praktikum dapat dilakukan dengan sesuai dan menghasilkan fenomena yang jelas serta kegiatan praktikum dapat berjalan dengan terarah. Kemudian 60\% dari 5 LKPD sudah menunjukan objek atau fenomena dapat teridentifikasi.Peristiwa utama atau objek dapat diidentifikasi dan konsisten dengan pertanyaan fokus, atau peristiwa dan objek dapat diidentifikasi tetapi tidak konsisten dengan pertanyaan fokus.(objeknya saja atau peristiwanya saja). Jika dilihat dari Teori, Prinsip dan Konsep, 60\% LKPD hanya memiliki salah satu teori yang relevan. Kurangnya konsep pada suatu LKPD dapat disebbakan oleh beberapa hal yaitu tidak terdapat pertanyaan yang akan dijawab siswa yang betujuan untuk memandu mengonstruksi teori yang ada (Ramadhayanti et al, 2020). Hal lain menurut Ridwan et al (2020) bahwa kegiatan praktikum ditujukan agar siswa mampu mengkolerasikan antara objek fenomena dengan ide yang ada sehingga kemampuan kogniitif, psikomor, dan afektif siswa dapat berkembang. Perekaman dan transformasi data didapatkan hasil hanya $40 \%$ 
LKPD yang memiliki perekaman data praktikum. Hal ini tentunya sangat rendah mengingat pentingnya perekaman data hasil praktikum untuk pelacakan data hasil pengamatan. dengan hasil pencatatan dan transformasi yang jika dibuatkan grafik maka dapat dilihat pada gambar 4.

\section{Aspek Konstruksi Pengetahuan}

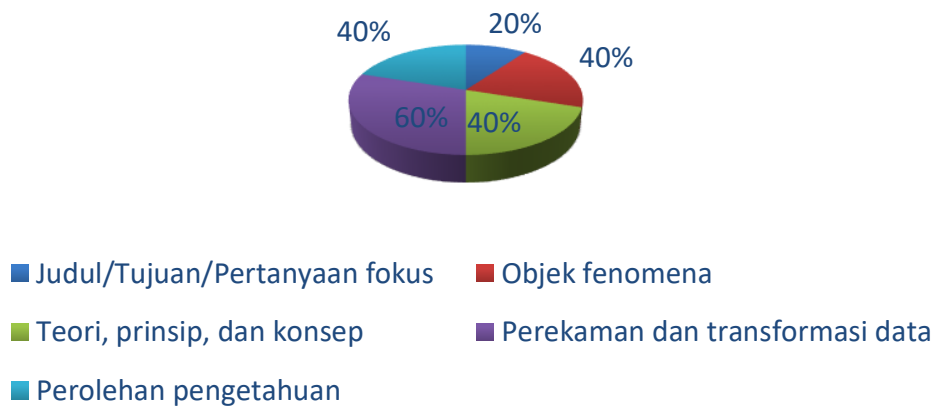

Gambar 4. Aspek Konstruksi Pengetahuan

\section{Analisis Praktikal}

Analisis Praktikal digunakan untuk menguji keterlaksanaan laboratorium, yang sesudah penelitian dihasilkan data tabel 4 .

Tabel 4. Hasil Analisis Aspek Praktikal

\begin{tabular}{|c|c|c|c|c|c|c|c|}
\hline \multirow{2}{*}{ Indikator } & \multirow{2}{*}{$\begin{array}{c}\text { Skor } \\
\text { maks. }\end{array}$} & \multicolumn{5}{|c|}{ LKPD } & \multirow{2}{*}{ Hasil } \\
\hline & & 1 & 2 & 3 & 4 & 5 & \\
\hline $\begin{array}{l}\text { Alat dan Bahan sesuai dengan standar } \\
\text { sekolah dan mudah didapatkan. }\end{array}$ & 3 & 3 & 3 & 3 & 2 & 3 & $\begin{array}{l}\text { Skor } 2=20 \% \\
\text { Skor } 3=80 \%\end{array}$ \\
\hline Alat dan bahan memiliki satuan yang jelas. & 3 & 2 & 2 & 2 & 2 & 1 & $\begin{array}{l}\text { Skor } 1=20 \% \\
\text { Skor } 2=80 \%\end{array}$ \\
\hline $\begin{array}{l}\text { Prosedur kerja terstruktur dan tidak } \\
\text { menimbulkan kesalahan. }\end{array}$ & 3 & 1 & 2 & 2 & 1 & 1 & $\begin{array}{l}\text { Skor } 1=60 \% \\
\text { Skor } 2=40 \%\end{array}$ \\
\hline $\begin{array}{l}\text { Objek dan fenomena muncul dan mudah } \\
\text { diamati melalui prosedur kerja. }\end{array}$ & 3 & 2 & 2 & 2 & 1 & 1 & $\begin{array}{l}\text { Skor } 1=40 \% \\
\text { Skor } 2=60 \%\end{array}$ \\
\hline $\begin{array}{l}\text { Tabel perekaman data sesuai dengan objek } \\
\text { fenomena yang muncul dan mudah di } \\
\text { interpretasi. }\end{array}$ & 2 & 3 & 2 & 1 & 1 & 1 & $\begin{array}{l}\text { Skor } 1=60 \% \\
\text { Skor } 2=20 \% \\
\text { Skor } 3=20 \%\end{array}$ \\
\hline
\end{tabular}

Analisis praktikal yang bertujuan untuk menganalisis keterlaksanaan kegiatan labolatorium. Pada Indikator Alat dan Bahan diperoleh hasil 100\% LKPD sudah sesuai dengan standar sekolah dan mudah didapatkan. Praktikum merupakan kegiatan pembelajaran yang menuntun siswa untuk aktif dengan diberikannya masalah dengan bantuan metode tertentu, alat, dan bahan (Ridwan et al, 2020). Jika LKPD tidak mencantumkan alat dan bahan atau ketersedian alat dan bahan yang sulit ditemukan maka kegiatan praktikum akan terkendala. Sedangkan hanya 80\% LKPD yang mencantumkan hanya sebagian alat dan bahan yang mempunyai satuan yang jelas. Hal ini tentunya dapat menyebabkan kebingungan pada siswa dalam melaksanakan praktikum karena alat dan bahan yang tidak terukur. Berdasarkan 5 LKPD didapatkan hasil $60 \%$ prosedur kerja tidak jelas dan menimbulkan kesalahan. Jika prosedur kerja tidak sesuai dengan tujuan maka tidak akan menunjukan hasil atau objek fenomena yang ingin diamati. Walaupun sudah banyak prosedur kerja yang disusun secara rinci, namun masih banyak prosedur kerja yang tidak terstruktur sehingga menyebabkan kebingungan dan multi tafsir oleh siswa (Nadia et al, 2020). Pada 5 LKPD hanya 3 LKPD atau 60\% yang mampu mengamati objek fenomena 
dalam bebrapa langkah kerja, namun 40\% lainnya langkah kerja tidak mampu mengamati objek fenomena. Padahal klaim pengetahuan dilihat dari objek fenomena yang menjadikan dasar pengetahuan bagi siswa (Ramadhayanti et al, 2020). Didapatkan hasil hanya 20\% atau 1 LKPD yang memiliki perekaman data yang sesuai dan mampu merekam objek fenomena secara keseluruhan dan 60\% LKPD memiliki tabel perekaman yang tidak sesuai dan tidak mampu merekam objek secara utuh. Pada praktikal ini, secara keseluruhan LKPD yang telah diperoleh, langkah kegiatan yang tercantum tidak jelas sehingga hal ini dapat membuat siswa kesulitan dalam mengerjakannya dan jika digambarkan maka terbentuk grafik dapat dilihat pada gambar 5 .

Analisis Praktikal
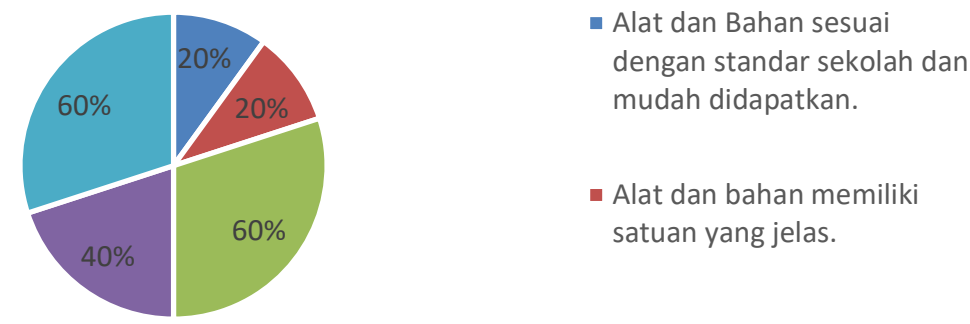

Gambar 5. Analisis praktikal

\section{Rekontruksi LKPD Yang Diharapkan}

Kegiatan rekonstruksi pada LKPD betujuan untuk memperbaiki dan menyempurnakan LKPD yang ada dengan menggunakan tiga aspek yaitu aspek konseptual, aspek praktis dan aspek konstruksi pengetahuan. Menurut Nadia et al (2020) rekonsturksi yang dilakukan pada aspek konseptual adalah perbaikan dan penyesuaian kompetensi dasar yang sesuai kurikulum dengan konten dan kompetensi yang terdapat pada LKPD. Pada konsep praktikal dilakukan rekonstruksi berupa berbaikan langkah kerja yang lebih tepat dan terstruktur sehingga mudah untuk dilakukan yang akan membantu siswa menemukan konsep, prinsip, dan teori berdasarkan interpretasi data yang ada.

Rekonstruksi LKPD juga dilakukan untuk memperbaiki komponen LKPD sehingga mempermudah siswa untuk melaksanakan praktikum dan tidak menimbulkan penafsiran ganda. Menurut Putri (2016) menyatakan bahwa komponen yang terkandung dalam suatu LKPD setidaknya harus mengandung 8 komponen yaitu 1). Judul, 2). Kompetensi dasar yang harus dicapai 3). waktu pengerjaan, 4). Alat dan bahan yang akan digunakan, 5). Informasi secara singkat, 6). Prosedur kerja, 7). Tugas yang akan dilakukan, dan 8). Laporan yang akan dikerjakan siswa.

Berdasarkan hasil analisis yang dilakukan pada 5 LKPD yang didapatkan dari berbagai sumber, penulis membuat rekonstruksi LKPD yang telah disesuaikan dengan kompetensi inti yang dimuat dalam materi Biologi Kelas X SMA di kurikulum 2013 yaitu KD 4.11 untuk merumuskan gagasan pemecahan masalah perubahan lingkungan yang terjadi di lingkungan. Terdapat pula beberapa komponen yang diperbaiki seperti fokus pertanyaan yang berguna untuk mengarahkan siswa pada objek fenomena yang akan diteliti. Selain itu perbaikan pada satuan alat dan bahan yang tidak jelas pada hampir semua LKPD yang ada. Kemudian perbaikan yang dilakukan yaitu perbaikan pada langkah kerja. Pada sebagian LKPD memiliki langkah kerja yang tidak terstruktur dan tidak sistematis, sehingga akan menimbulkan kesulitan dalam pelaksanaan praktikum dan menemukan objek fenomena yang akan diamati. Perbaikan selanjutnya yaitu pada perekaman data. Pada beberapa LKPD masih belum memiliki perekaman data 
yang belum sesuai sehingga tidak mampu merekam semua data dari objek fenimena yang muncul pada praktikum.

Pada 5 sampel LKPD yang dianalisis didapatkan hasil judul/tujuan/fokusnya tidak memfokuskan pada objek atau fenomena yang akan muncul. Indikator lainnya yaitu interpretasi data dan transformasi data menunjukkan hasil jika kegiatan praktikum yang dilaksanakan sebagian belum mengarahkan siswa untuk membuat interpretasi data yang sesuai dan pada transformasi data, beberapa LKPD mengarahkan siswa hanya menyajikan data penelitian secara sederhana. Sedangkan untuk tingkat kemampuan berpikir pada 4 LKPD hanya mengarah ke mengaplikasikan (C3) dan 1 LKPD mengarah kemampuan berpikir menganalisis (4). Kegiatan rekonstruksi LKPD merupakan upaya dalam memperbaiki kesalahan-kesahalah dan ketidak sesuaian yang sering muncul pada praktikum pengaruh limbah deterjen terhadap aktivitas ikan berdasarkan analisis dan uji coba terhapat 5 sampe LKPD yang telah dilakukan :

DESAIN KEGIATAN LABORATORIUM

Nama

Kelompok :

Kelas

PENGARUH LIMBAH DETERJEN TERHADAP AKTIVITAS IKAN

Kompetensi Dasar :

3.11 Menganaslisis data perncemaran lingkungan, penyebab, dan dampaknya bagi kehidupan.

4.11 Merumuskan gagasan pemecahan masalah pencemaran lingkungan yang terjadi di lingkungan sekitar.

A. Tujuan :

1. Siswa dapat memahami dampak pencemaran air terhadap organisme khususnya ikan yang hidup di alirannya.

2. Siswa dapat menganalis perbedaan ikan yang hidup di air bersih dan tercemar

3. Siswa dapat merancang pencegahan dan penanggulangan pencemaran air.

B. Landasan Tori

Pencemaran air merupakan salah satu penyebab penurunan kualitas lingkungan. Air yang kita gunakan setiap hari semakin terancam oleh keberadaan bahan pencemar seperti bahan biologi (Escherichia coli, Entamoeba coli, dan Salmonella thyposa), bahan kimia (pestisida, detergen, dan pupuk anorganik), dan bahan fisik (plastik, kaleng, dan botol). Salah satu bahan yang sering digunakan manusia dalam kehidupan sehari-hari adalah detergen. Detergen digunakan di rumah tangga sebagai bahan pembersih, salah satunya untuk mencuci pakaian. Jenis detergen yang banyak digunakan merupakan detergen tergolong keras karena mengandung surfaktan berupa ABS (Alkyl Benzene Sulphonate) dan bahan kimia berbahaya lain. Kandungan tersebut membuat detergen sukar diuraikan oleh mikroorganisme (nonbiodegradable) sehingga dapat menimbulkan pencemaran lingkungan. Air yang tercemar oleh detergen dapat mengancam kehidupan organisme yang hidup di dalamnya, salah satunya adalah ikan. Selain ikan masih banyak organisme lain, seperti fitoplankton, zooplankton, cyanobacter, dan lain-lain. Jika organisme-organisme seperti fitoplankton mati, maka zooplankton akan mati karena tidak ada makanan, ikan-ikan pun akan mati karena zooplankton yang biasa dimakan tidak ada. Dengan kata lain detergen dan polutan lainnya yang mencemari air dapat memusnahkan seluruh organisme yang hidup di dalamnya. Besar tidaknya pengaruh detergen dan polutan lainnya pada ikan dan makhluk hidup lain tergantung pada konsentrasi polutan tersebut. Semakin tinggi konsentrasi polutan, semakin besar pengaruhnya.

C. Alat dan Bahan

Alat yang digunakan

1. Aquarium/ Toples Bening 3 buah

. Pengukur waktu satu buah

Sendok pengaduk 3 buah

1. Ikan mas 3 buah berukuran sama.

Timbangan 1 buah

5. Alat tulis 


\section{Langkah Kerja}

1. Sebelum melakukan pekerjaan di Laboratorium, tetapkan prosedur ilmiah dan keselamatan kerja dalam percobaan ini. Taatilah tata tertib keselamatan kerja selam proses percobaan di Laboratorium.

Siapakan alat dan bahan yang akan digunakan.

2. Masukan air sebanyak $500 \mathrm{ml}$ di masing-masing aquarium yang sudah disiapkan. Buatlah label pada setiap aquarium.

3. Timbanglah deterjen dengan berat $10 \mathrm{gr}$ dan $20 \mathrm{gr}$.

4. Masukan deterjen pada masing-masing aquarium.

Aquarium 1 : tidak ada detergen

Aquarium $2: 10 \mathrm{gr}$ deterjen

Aquarium 3: $20 \mathrm{gr}$ deterjen

5. Aduk hingga deterjen dan air tercampur.

6. Masukan ikan pada masing-masing aquarium

7. amatilah pergerakan operkulum ikan, pergerakan sirip ikan, dan warna sisik setiap 5 menit selama 15 menit.

8. catat hasil pengamatan di tabel hasil pengamatan.

F. Tabel Hasil Pengamatan

\begin{tabular}{|c|c|c|c|c|}
\hline \multirow[t]{2}{*}{ Waktu } & \multirow{2}{*}{$\begin{array}{l}\text { Aqua } \\
\text { rium }\end{array}$} & \multicolumn{3}{|c|}{ Kondisi Ikan } \\
\hline & & Pergerakan operkulum & $\begin{array}{c}\text { Pergerakan s } \\
\text { irip }\end{array}$ & Warna sisik \\
\hline \multirow{3}{*}{5 menit } & 1 & & & \\
\hline & 2 & & & \\
\hline & 3 & & & \\
\hline \multirow{3}{*}{10 menit } & 1 & & & \\
\hline & 2 & & & \\
\hline & 3 & & & \\
\hline \multirow{3}{*}{15 menit } & 1 & & & \\
\hline & 2 & & & \\
\hline & 3 & & & \\
\hline
\end{tabular}

\section{G. BAHAN DISKUSI}

1. Berdasarkan data hasil pengamatan, bagaimanakah aktivitas ikan pada tiap-tiap aquarium ?

2. Mengapa kondisi ikan berbeda-beda tiap aquarium ?

3. Jika 3 botol dalam percobaan kalian diibaratkan 3 sungai yang berbeda. Manakah sungai yang tercemar? Jelaskan kasus tersebut menghubungkan dengan pengertian pencemaran!

4. Berdasarkan tempat terjadinya dan berdasarkan sifat polutannya, termasuk jenis pencemaran lingkungan apakah kasus dalam pereobaan kalian?

5. Kegiatan manusia apakah yang dapat menyebabkan kasus dalam percobaan kalian, sebutkan minimal 3 kegiatan lain manusia yang dapat menimbulkan pencemaran/kerusakan lingkungan!

6. Bagaimana dampak detergen/ zat kimia berbahaya yang masuk ke perairan terhadap kehidupan biota di perairan tersebut dan manusia yang memanfaatkan biota tersebut ataupun memanfaatkan air dalam perairan?

7. Bagaimanakah cara penggunaan detergen yang baik sehingga tidak menimbulkan pencemaran perairan?

8. Jika sudah terjadi pencemaran detergen pada suatu perairan, bagaimanakah cara mengatasinya? Sebutkan juga minimal 3 upaya yang dapat dilakukan untuk mengatasi pencemaran/kerusakan lingkungan!

9. Kembangkanlah kesimpulan berdasarkan hasil percobaan!

10. Buatlah laporan hasil percobaan dan produk (Karya Ilmiah atau Poster) upaya pencegahan dan penanggulangan pencemaran air yang dapat dilakukan secara nyata di lingkungan sekitar mu! 


\section{SIMPULAN}

Berdasarkan hasil penelitian analisis terhadap 5 sampel LKPD materi pencemaran lingkungan dapat disimpulkan bahwa seluruh LKPD sudah hasil analisis dan uji coba pada 5 LKPD materi pencemaran lingkungan ditemukan bahwa semua sampel LKPD sudah memiliki kompetensi dan konten yang sesuai dengan KD yang ada di kurikulum pendidikan. Namun, masih ada LKPD yang tidak sesuai dengan komponen inti yang harus dimiliki dalam LKPD seperti belum mengarahkan siswa untuk dapat melakukan observasi dengan baik, interpretasi data yang tidak lengkap, dan belum melatih kemampuan berpikir tingkat tinggi pada siswa. Serta tidak lengkapnya komponen LKPD seperti judul/tujuan/ pertanyaan fokus serta objek fenomena yang akan diamati dapat menyebabkan kebingungan pada siswa sehingga dapat memunculkan penafsiran ganda terhadap. Dari beberapa sampel LKPD yang diamati masih ada LKPD yang tidak memiliki keterangan satuan alat dan bahan serta kesusaian prosedur kerja pada praktikum juga. Hal ini tentu sangat berpengaruh dalam proses praktikum, tidak adanya keterangan satuan alat dan bahan serta tidak runut dan sesuainya prosedur kerja tentu akan mempengaruhi proses dan objek/fenomena yang akan didapatkan.

\section{RUJUKAN}

Ariani, D., Meutiawati, I., \& Lkpd, K. K. (2020). Jurnal Phi Pengembangan Lembar Kerja Peserta Didik (LKPD) berbasis discovery learning pada materi. 1(3), 13-19.

Arnop, O., Budiyanto, B., \& Saefuddin, R. (2019). Kajian Evaluasi Mutu Sungai Nelas Dengan Metode Storet Dan Indeks Pencemaran. Naturalis: Jurnal Penelitian Pengelolaan Sumber Daya Alam Dan Lingkungan, 8(1), 15-24. https://doi.org/10.31186/naturalis.8.1.9158

Hasibuan, R. (2016). Analisis Dampak Limbah/Sampah Rumah Tangga Terhadap Pencemaran Lingkungan Hidup. IImiah, 04(01), 42-52.

li, B. A. B., Teori, A. K., Kerja, L., \& Didik, P. (2012). Pengembangan Lembar Kerja..., Agus Kurniawan, FKIP UMP, 2015. 9-28.

Iman Ridwan, Sri Anggraeni, \& Bambang Supriyatno. (2020). Analisis Lembar Kerja Peserta Didik Sekolah Menengah Atas Pada Praktikum Uji Urin. Biodik, 6(3), 321-331. https://doi.org/10.22437/bio.v6i3.9462

Lampung, U. (2013). Pentingnya LKPD pada Pendekatan Scientific Pembelajaran Matematika. 217225.

Landrigan, P. J., \& Fuller, R. (2015). Global health and environmental pollution. International Journal of Public Health, 60(7), 761-762. https://doi.org/10.1007/s00038-015-0706-7

Mata Pelajaran, P., Bahan, P., \& Bagi, M. (2016). Pengembangan Lembar Kerja Siswa (Lks) Sebagai Bahan Ajar Siswa Kelas X Jasa Boga Smk Muhammadiyah 1 Moyudan Proposal Skripsi.

Nadia, N., Supriatno, B., \& Anggraeni, S. (2020). Analisis dan Rekonstruksi Komponen Penyusun Lembar Kerja Peserta Didik Struktur dan Fungsi Jaringan Tumbuhan. Biodik, 6(2), 82-94. https://doi.org/10.22437/bio.v6i2.9439

Permadi, I. M. A., \& Murni, R. . R. (2013). Dampak pencemaran lingkungan akibat limbah dan upaya penanggulangannya di kota denpasar. Kertha Negara, 1, 3-7. 
Pratama, G., Kurniawan, I. D., \& Ilhamdy, A. F. (2020). Pengendalian Pencemaran Limbah Domestik sebagai Upaya Rehabilitasi Pesisir di Desa Malangrapat, Kabupaten Bintan. PRIMA: Journal of Community Empowering and Services, 4(1), 45. https://doi.org/10.20961/prima.v4i1.41228

Ramadhayanti, Anggraeni, S., \& Supriatno, B. (2020). Analisis dan Rekonstruksi Lembar Kerja Peserta Didik Indra Pengecap Berbasis Diagram Vee. Biodik, 6(2), 95-108. https://doi.org/10.22437/bio.v6i2.9441

Studi, P., Biologi, P., Pascasarjana, P., \& Makassar, U. N. (n.d.). Karakteristik Lembar Kerja Peserta Didik ( LKPD ) pada SMA Biologi di Kota Makassar Characteristics of Student Worksheets (LKPD) at Biology High School in Makassar City. 292-295. 